\title{
Linguce é
}

\section{Rivista di lingue e culture moderne}

$\begin{array}{ll}\text { Nota sugli Autori } & 7\end{array}$

Roberta Mullini $\quad 11$

Editoriale

Fabio Ciambella

Danza, lingua e potere: (s)cortesia ne La dodicesima notte di Shakespeare

Daniela Francesca Virdis

"Lay down branch roads, provide town sites, build barracks":

A Practical Stylistic Investigation of Hyde Clarke's Colonization, Defence, and Railways in Our Indian Empire (1857)

Alessandra Calanchi

Quando manca il detective. La presa in carico dell'investigazione in due racconti americani di fine Ottocento

(When the Detective is Missing: Taking Charge of the Investigation in Two Late Nineteenth-Century American Short Stories)

Beatrice Nori

Dreadful Dolls: Female Power in Carol Ann Duffy 
Lo jurodivyj in Nostalghia. Genesi ed evoluzione di Domenico nella sceneggiatura di Tarkovskij e Guerra

(The jurodivyj in Nostalghia: The Character of Domenico in Andrej Tarkovskij and Tonino Guerra's Script Writing)

Alessandra Pettinelli, Chiara Sola, Monique Carbone Cintra,

Luca Avellini

E-learning e futuri studenti in mobilità internazionale. Riflessioni

su aspetti e potenzialità di un corso di lingua italiana

(E-Learning and Future Students in International Mobility:

Considerations about Aspects and Makings of an Italian Language

Course)

Cecilia Lazzeretti

Communicating Sustainable Tourism in English and Italian:

A Contrastive Analysis

Cristina Solimando

Linguistic Interference and Religious Identity: The Case

of a Lebanese Speech Community

RECENSIONI 


\title{
Linguistic Interference and Religious Identity: The Case of a Lebanese Speech Community
}

\section{Cristina Solimando}

Università degli Studi Roma Tre cristina.solimando@uniroma3.it

DOI: https://doi.org/10.7358/ling-2020-002-soli

\begin{abstract}
Multilingualism and multiculturalism are cornerstones of Lebanese society. There is a considerable amount of Arabic-French bilingualism, although English has been rapidly gaining ground in recent years. This situation has obviously affected the Lebanese dialect: loan words and even cases of phonological, morphological and syntactical change are widespread. Moreover, we constantly witness phenomena of code-switching and linguistic mixing between Lebanese/French and Lebanese/ English. This has become associated with a certain cultural and religious identity. The literature that investigates the role of foreign languages in Lebanon generally focuses on their use in Lebanese education and on the speakers' perception of the foreign languages. The present study examines the role of foreign languages in authentic speech and explores the linguistic phenomena of code-switching and code-mixing as markers of speaker religious identity. Various extracts of authentic informal speech are analysed in order to define further the correspondence between language study and identity in the Lebanese context.
\end{abstract}

KEYWORDS - code-switching; code-mixing; linguistic interference; Lebanese dialect; religious identity.

\section{INTRODUCTION}

It is often claimed that multilingualism and multiculturalism are cornerstones of Lebanese society. For many generations now, Lebanon has adopted Lebanese Arabic (LA) as the spoken language and Modern Standard Arabic as the official written language. In addition, there is a considerable amount of Arabic-French bilingualism, although English has been rapidly gaining ground in recent years. In the area of mass media communication, Arabic remains the major vehicle of daily news whether in newspapers, on the radio or on the television. This situation is also the result of the vital presence of foreign languages in the country. Many schools use French and English as the 
languages of instruction, and university education is increasingly dominated by English. This situation has obviously affected the Lebanese dialect: loan words and even cases of phonological, morphological and syntactical change are widespread. For this reason, we constantly witness phenomena of codeswitching and linguistic mixing between Lebanese/French and Lebanese/ English. This phenomenon, however, seems limited to the younger generations of the middle and upper classes: in fact, bilingualism is consolidated in the international schools and universities attended by students of more privileged groups. However, the use of English and French lexical borrowings in speech has become associated not only with a higher social status among young people, but with a certain cultural and religious identity.

The present study, based on 23 hours of informal conversations, aims to investigate the phenomena of code-switching and code-choice among Lebanese post-university students with respect to their religious background. The participants are 18 post-university students: 10 males and 8 females. A preliminary questionnaire was distributed to each of them in order to collect data about their sex, age, religious affiliation, educational background and the first foreign language learned. The questionnaire also contained one open question about the role of their first foreign language in their everyday speech.

The literature that investigates the role of foreign languages in Lebanon generally focuses on their use in Lebanese education, either from a historical perspective or in the light of more recent policies. An interesting study by Diab (2009) discusses the perceptions of Lebanese university students regarding their ethnic, national and linguistic identities, and their favoured first foreign language and medium of instruction in pre-university schools. Findings revealed that Lebanese university students valued the importance of English as an essential language due to its status as an international language, while those whose first foreign language was French expressed a strong affiliation with French language and culture. Moreover, students from a Christian religious background were much more likely than their Muslim counterparts to construct an identity that was ethnically and culturally distinct from the rest of the Arab world. In Shaaban and Ghaith's (2002) analysis of Lebanese university students' perception of the linguistic vitality of Arabic, French and English, it clearly emerges that the Lebanese largely associate French with Christians and English with Muslims. The results also showed that English was perceived as more vital than Arabic as a carrier of culture and as a status symbol both in Lebanon and abroad, while Arabic was perceived as more vital than English as a symbol of identity. 
The present study intends to take this discussion further by examining the role of foreign languages in authentic speech, and by exploring the linguistic phenomena of code-switching and code-mixing as markers of speaker identity and the individual's sense of self and community. In order to define the correspondence between language study and identity in the Lebanese context more precisely, I will draw upon extracts of authentic informal speech to uncover the most frequent and significant instances of English and French interference in the Lebanese dialect.

The paper is structured as follows: sections 2 and 3 provide an overview of the Lebanese education system and the role of foreign languages in education. Section 4 takes a more in-depth look at the influence of the foreign languages in question through a reflection on their relation to cultural identity and the idea of citizenship. Finally, section 5 presents and discusses the findings, and positions the study in relation to the theoretical background.

\section{AN OVERVIEW OF LANGUAGE POLICY IN LEBANON}

Lebanon's specific geographical position between East and West makes it extremely receptive to different cultures and languages. The teaching of languages other than the native language in pre-university education took place in three phases (Frayha 1999). The first phase was characterized by the presence of missionaries in the region between the 17th and the 20th centuries. Owing to its varied confessional nature, Lebanon managed to maintain a great degree of autonomy under Ottoman rule (1516-1918), and this allowed European states to exert a great deal of influence on the affairs of the country through their support of communities that shared the same religious faith. France thus sided with the Maronites and Catholics, Turkey with the Muslims and Great Britain with the Druzes. The most active missionary groups were the French and the Americans, who "in the mid-nineteenth century established schools which trained many of the future Lebanese political leaders and brought Western ideas strongly to bear on the culture" (Nydell 1996, 149). Ottoman-European relations led to the foundation of private schools in which French and English were used in addition to Arabic ${ }^{1}$. The competi-

${ }^{1}$ This period also witnessed a revival of Arabic thanks to the efforts of some missionary schools and of a large number of Lebanese poets, essayists and fiction writers who had studied at these schools. See Suleiman 1994. 
tion between the French Jesuits and the American Evangelical Protestants resulted in the establishment of many schools throughout the country, culminating in the founding of the Syrian Protestant College (now the American University of Beirut) in 1886 and St. Joseph University in 1875. The second phase, during the French Mandate (1920-1943), consolidated the use of French by making Arabic and French compulsory in private schools. The French colonial authorities also tried to impose their cultural and linguistic dominance (Calvet 1987) by making French the medium of instruction for humanistic studies and the sciences. This decision helped to make French the language of the political and cultural elites. In this phase, the Jesuits increased the number of religious schools in the country: most students in these schools were Christians and this created resentment among Muslims who believed that the French authorities were establishing and supporting a Christian political and economic elite. Arabic nationalists, seeing that Arabic was being side-lined, argued that language is not just a means of communication, but the most obvious symbol of group identity (Suleiman 1994, 3), and they strongly resented this new French-dominated educational system. With the third phase, which began in 1943 with the independence of Lebanon from French governance, schools teaching English as the second foreign language increased (Atiyeh 1970). English was also introduced in 1946 as a second foreign language option on a par with French. However, the number of students who studied English only increased significantly after the 1970s when English became an important means of communication worldwide. At a university level, the AUB (American University of Beirut), which had established Arabic as the medium of instruction since its foundation, contributed strongly to the rise of English, choosing it in place of Arabic in 1996.

The new National Language Curriculum, approved by the Council of Ministers in 1994, required all schools to teach a second foreign language: schools, in addition to Arabic, had to have either English or French as the first foreign language in addition to a second foreign language. Previously, the fifteen years of war from 1975 to 1990 had interrupted growth and development in the educational sectors quite severely. Since then, however, both high school and university level education have seen reforms to their infrastructure, syllabuses and the training of qualified personnel, with a whole new national curriculum set up based on the principles of communication, cultural awareness, interactive learning and the integration of skills. In this period, the importance of foreign languages became evident: English-medium education established a place in traditional French "territory" through the Lebanese 
American University (LAU), Balamand University (established by the Greek Orthodox community) and al-Manār University (established by the Sunni community). The war had intensified divisions and hostilities in the country and such hostility was often expressed in linguistic and cultural terms. The establishment and expansion of these universities seemed to mirror the divisiveness in the country that had emerged during the war, despite their acceptance of students of all religions. In this period, notwithstanding the importance given to the learning of foreign languages, educational institutions also tried to revitalize Arabic given that it was still a symbol of the Lebanese identity, and its colloquial variety was the general means of social interaction. Arabic is the teaching language for all subjects in all public as well as in many private elementary schools. Furthermore, it remains the teaching language for the humanities at secondary levels, and even, in some cases, for science and mathematics that are generally taught in English (Basha and Bahous 2011).

In recent years, the expansion of English at the expense of French is becoming more evident: even French schools admit the need for English as the language of wider communication and as the language of higher education, and this explains the introduction of English in the teaching of business administration classes at university level. As we will see in the next section, the importance of French no longer relates to its cultural importance, but to its close association with Christianity.

\section{The Lebanese Education System: SOCiAL Class AND CONFESSIONAL SECTARIANISM}

Lebanon is widely known for its high level of education, particularly at university level. Nevertheless, the education system has not been able to reduce the sectarian divisions and the social inequalities that affect Lebanese society (Frayha 2009). As we saw in the preceding section, the first modern forms of schooling, which existed before any form of central state control, were based on a sectarian institutionalization of knowledge. Most of the schools established in the mid-1920s were private and religious (Frayha 2003) and, as with the Lebanese governments that followed, the French administration was not able to centralize the educational system due to political and religious opposition. Legislation relative to education strengthened religious autonomy and, consequently, private schools: in this respect, each community 
was granted the opportunity to organize its own schools, thus creating diversified curricula throughout the country. Moreover, disputes between political and religious leaders had emphasized the sectarianism within education, so parliament recognized the right for all religious communities "to give the prior permission to all book, visual and audio publications that address the religious ideology of the sect" ${ }^{2}$.

The Lebanese education system also had to face up to the problem of social and qualitative disparities between schools and regions. Indeed, a dual system operates on a social level, with private education receiving students from middle and upper groups, while public education is for the lower middle class and poorer social groups (Suleiman 1994, 130): public and private schools thus cater for students from different social classes, and they offer a different standard and quality of education. The gap between the various social classes has become wider and deeper; indeed, only parents who can pay the high tuition fees are able to send their children to private schools (Inati 1999). Moreover, private schools offer quality education and boast high percentages of student success in national examinations compared to public school students (NCERD 2000). Inevitably, the level of foreign language proficiency also differs between the various schools: private education generally caters to higher expectations and provides better instruction in at least one foreign language (Bahous and Nabhani 2008).

\section{Foreign LANGUAGES IN HIGHER EDUCATION AND THE IMPLICATIONS FOR IDENTITY}

Language is a product of the process of humans attempting to coordinate their existence in relation to actions, communities, and other individuals. It has been established that language does not stand alone, but is related both directly and indirectly to social, political, historical and other extra-linguistic factors (Spolsky 2004). Social and political change has often consequences on language use: inevitably, code-choice reflects political and social standing and, in most cases, is a reflection of an identity, whether individual or collective.

Lebanon is often labelled as an Arab country, but its history and the political events that have shaped it have made the issue more complex. As

\footnotetext{
${ }^{2}$ From the UNDP 2009, 23 quoted by Frayha 2009.
} 
Suleiman (2006) pointed out, the Lebanese identity is based upon a duality: the Arabic Lebanon and the Lebanese Lebanon. For the former, the Arab Middle East is the area they belong to, while for the second, the Middle East is the area where they live. For some Lebanese, national identity is neither purely Arab nor Western, as they partake of both, while remaining genuinely authentic and true to their roots. I remember a gaffe I once made during a lecture in Beirut when I addressed the public as Arabs. While Muslim participants did not particularly react to my statement, the Christians present reacted vociferously: "We are not Arabs, we are Lebanese and our origins are Phoenician". Their reaction evidenced, on the one hand, their feeling of being from a unique country with Phoenician roots and Western affinities, distinct from the Arab environment and, on the other hand, the strong relationship between citizen identity and sectarian affiliation. As Diab (2009) rightly observes, the influence of religious background on Lebanese perceptions of ethnic, national and linguistic identity is confirmed by the responses given by her interviewees: the overwhelming majority of Muslim students perceive Lebanese people as Arabs, while Christian students were much more evenly divided in their perceptions. Not surprisingly, the latter are much more likely to construct an identity of themselves that is ethnically and culturally distinct from the rest of the Arab world.

As discussed in the previous section, the teaching of foreign languages in the Lebanese educational system is closely related to the religious affiliations of the individual schools. Undoubtedly, multilingualism characterizes Lebanon and represents one of the strengths of the country; indeed, in 1997 Lebanese education policy stipulated that all Lebanese education has to be trilingual from early on: from the start of school, children are taught two or three languages - Arabic ${ }^{3}$, English and French - and two alphabets. Scientific subjects, and often other subjects too, are taught both in English and French, given that Francophone secondary schools represent $65 \%$ of Lebanese secondary schools. An attempt to Arabize the language of teaching was made in some schools, but gave way to the fact that scientific and humanistic studies in universities are taught in a foreign language. This narrows the chances for Arabic to gain traction; in fact, multilingualism contributes inesti-

${ }^{3}$ By using the term Arabic, we intend Modern Standard Arabic (MSA) that corresponds to the written and official language. In contrast, Lebanese Arabic is the language that is actually used in everyday life. Standard Arabic and its grammar are school subjects, just like French and English. 
mably to the success of the Lebanese both in Lebanon and abroad (Daccache 2013). Nevertheless, it is evident that the multilingual education approach also highlights problems of cultural identity, a crucial factor in a country like Lebanon. Arabic is assumed to be the first language, but, due to its diglossic nature, Standard Arabic is not used in conversation inside or outside the classroom. Moreover, in many Maronite homes, French has long been the preferred language of social intercourse, as English has been in some Greek Orthodox as well as in some Muslim homes. In such circles, Arabic has often been relegated to a position of inferiority, and some Lebanese never master it at all (Beer and Jacob 1985). Indeed, one of the controversial languagerelated issues that divided the various Lebanese groups was the role of native versus foreign languages in society, communication, and education. In their study conducted through interviews with 176 university students, Shabaan and Ghaith demonstrate the correlation between attitudes towards French and English and religious affiliation. They underline three results that are of interest here:

First, Arabic was perceived by the majority of participants as the most vital language for talking about daily events and news (93\%), discussing daily concerns $(89 \%)$, talking to family $(88 \%)$, talking for fun $(85 \%)$, conversing at parties $(79 \%)$, discussing literature (69\%) and talking to peers at school (67\%).

Second, most of the participants see French as the preferred foreign language (FL) of Christians (97\% associate it with the Maronites, $85 \%$ with the Catholics and $71 \%$ with the Orthodox), and English as the preferred FL of Muslims (82\% associate it with the Sunnis, $70 \%$ with the Shiites and $70 \%$ with the Druses). Furthermore, it is observed that among Christians, English is associated by 47 percent of the participants with Protestants, by 37 percent with the Armenians [...]. On the other hand, among Muslims, French is associated by 20 percent with the Druses, by 13 percent with the Shiites, and by 8 percent with the Sunnis.

Third, the majority of the participants perceived English to be the most vital language for use in the domains of science and technology [...], university education [... and business ...]. Meanwhile, French was perceived as somewhat vital in the domains of intermediate education [... and in] cultural activities. $(2002,564)$

These results confirm the importance and the effects that missionary schools and foreign governance exerted on the linguistic situation in Lebanon. Multilingualism has resulted in a code alternation that characterizes not only the Lebanese variety, but in some way, Lebanese culture as a whole (Joseph 
2004). The vitality of a language, as underlined in Shabaan and Ghaith's study, relates to the social, cultural and educational factors that define the continued existence and prosperity of a language in heterogeneous communities. Heterogeneity, in this context, does not mean only ethnic diversity, but also a diversity of beliefs, perceptions and aspirations. Code-choice must thus be considered within these parameters.

\section{THE STUDY}

\subsection{Theoretical background}

The purpose of the present study is to demonstrate that there is a correlation between code-switching and code-mixing, and the social and religious identity of the participants in question. Code-switching occurs when a speaker wishes to redefine an interaction through social and identity linguistic codes. Kachru (1978) distinguishes between code-switching and code-mixing. Codeswitching relates to the distinct functional contexts in which a multilingual speaker makes alternate use of two or more languages, while code-mixing refers to the use of two or more languages in the transfer of linguistic units from one language to another. Sridhar (1978) refines this distinction by positing that in code-switching the switch from one code to the other indicates a corresponding switch in the social situation, whilst alternation in code-mixing code takes place almost unconsciously within the social event meaning that the speaker cannot account for every instance of the shift. Secondly, in codemixing, the mixed elements have equivalents in the other code and they may exist side by side, while in code-switching one code may lack certain lexical terms. Moreover, speakers may code-switch when they lack proficiency in a certain code; in code-mixing, they tend to mix the languages they know.

Blom and Gumperz (1972) distinguish two types of code-switching: situational and metaphorical. Situational switching is where the alternation between varieties redefines a situation, marking a change in the governing norms. Metaphorical switching occurs when alternation enriches a situation, allowing for an allusion to more than one social relationship within it, and it may also include shifts for emphatic purposes. This classification is useful because it allows us to describe how and when code-switching occurs. In 
order to understand the reasons for code-switching, we need to see the switch as an extension of the speaker: this entails exploring the relationships at play between the subject of the discourse, the participants of an interaction and the societal norms which give language choice its meaning. Identity and status are linked to language choice through a process of role-taking: on the basis of societal norms and long- and short-term personal goals, a speaker decides what role to adopt in a given interaction. Making a language choice is part of this role-taking.

In their study on the functions of code-switching in Kenya, MyersScotton and Ury (1977) do not consider the use of single, well-established loanwords or phrases as code-switching. In most cases this position is correct: for instance, using the word "weekend" does not signify an act of codeswitching to English. In the same way, there are several necessity loanwords in Standard Arabic, especially in the technological and scientific fields. Some of them have been assimilated into the linguistic system through mechanisms of morphologization (e.g., talfana 'to phone'), while others are used in the Arabic transliterated form. In any case, none of these instances evidence code-switching. In the Lebanese colloquial variety, however, the situation is more complex: the prolonged use of foreign languages (mainly English and French) in the country and the influence that they exert through the Lebanese education system has had a strong effect on the vernacular. Words and expressions have entered common speech, sometimes without any perception of linguistic alterity on the part of speakers. For instance, the greeting formula Hallo, kiff-ak, ça va?, in which English, Lebanese and French occur together, is so common that Lebanese speakers use it without reflecting on the linguistic interference of English and French. Similarly, merci is so widespread in everyday conversation that even speakers who do not know French use it without considering it a foreign word. These cases, evident signals of the role exerted by foreign languages over the years, cannot be considered cases of code-switching since, without any awareness on the part of the speaker, they are not part of the role-taking process. Other loanwords have undergone morpho-phonological processes of assimilation, and are used above all in the speech of the younger generation. An example of this is pannik-t, 'I was in a panic', in which the English word panic is verbalized through the addition of the past time morpheme $-t$. These instances are markers of a long process of linguistic interference in which the purpose of code-switching is generally a redefining of identity achieved through an ongoing negotiation between speakers that affects the nature of the interaction. 


\subsection{Participants}

The participants in this study were a sample of post-university students (18 participants: 14 graduates from private universities and four from state universities) chosen on the basis of their age (23-28 years old), sex (10 males and 8 females) and religious affiliation (10 Sunnis, 6 Christians and 2 Druze). Ten participants had English as their first foreign language, 5 had French and $3 \mathrm{had}$ other languages. These last eight were, however, also proficient in English.

Other considerations were made in selecting these participants: their diverse religious affiliations, their awareness of the effects of their educational and socio-economic backgrounds on their linguistic attitudes and abilities, and the fact that they had known each other for several years. I considered this aspect significant as the interaction could be taken to be more spontaneous and less constrained by the formality that might otherwise have characterized the conversations.

\subsection{Je t'aime habībì so much! Cases of interference and types of insertion}

The aim of the study was to classify all the utterances in which speakers recur to codes different from the Lebanese variety by noting two different kinds of insertion. Insertion is said to be akin to spontaneous lexical borrowing and, depending on the languages involved, may consist of single bare nouns or phrases (Muysken 2000, 95). Here we consider the insertion of words (including cases of repetition) and the insertion of phrases and interjections. The speakers are indicated as M1, M2, M3 etc. for the Muslim speakers and as C1, $\mathrm{C} 2$ and $\mathrm{C} 3$ for the Christian speakers. Brief but significant extracts of conversation are presented below, followed by the translation. All Lebanese sentences are transliterated, and the foreign language insertion is noted in brackets.

\subsubsection{Insertion of words}

The insertion of one or more foreign words in the Lebanese conversations analysed mostly relate to a code-mixing phenomenon: the words inserted in the utterances have equivalents in the native language, although they are occasionally not very common in everyday speech. 


\section{Extract 1}

$\mathrm{M}_{1}$ : Hāy gāys (Hi guys)! Kîf-k.ōn?

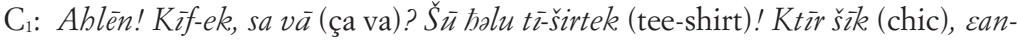
žad!

$\mathrm{M}_{1}$ : acğabek, əl-lūk (look) əž-ždid?

$\mathrm{M}_{2}$ : mən wèn əštarēto?

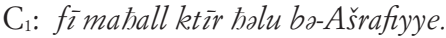

$\mathrm{M}_{1}$ : Hi guys!? How are you? / $\mathrm{C}_{1}$ : Hello! How are you? Is it ok? Your tee-shirt is so nice! Very chic, really! / $\mathrm{M}_{1}$ : do you like my new look? / $\mathrm{M}_{2}$ : where did you buy it? / $\mathrm{C}_{1}$ : There is a very nice shop in Ashrafiyyeh.

\section{Extract 2}

$\mathrm{M}_{1}$ : al-kwōliti (quality) ktīir bāy (high)!

$\mathrm{M}_{2}$ : aywa, Ay sì (I see), w kamēn al-kāmera (camera) ktīr profě̌šonal (professional)!

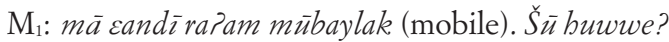

$\mathrm{M}_{2}$ : Ou siks seven trīêyt (O six seven three eight)...

$\mathrm{M}_{1}$ : It is a very high quality! / $\mathrm{M}_{2}$ : Yes, I see, and also the camera is so professional! / $\mathrm{M}_{1}$ : I don't have your telephone number. What is it? / $\mathrm{M}_{2}$ : o six seven three eight...

\section{Extract 3}

$\mathrm{M}_{1}: \breve{S}_{\bar{u}} \check{s} \bar{o} b$ al-yōm, tū hōt (too hot)!

$\mathrm{C}_{2}$ : Wi, sè šōo (c'est chaud)! Mnrūt a la plāž?

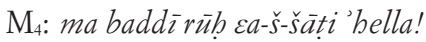

$\mathrm{M}_{1}$ : It's so hot today, too hot! / $\mathrm{C}_{2}$ : Yes, it's hot. Shall we go to the beach? / $\mathrm{M}_{4}$ : I don't want to go to the beach now!

\section{Extract 4}

$\mathrm{M}_{3}$ : wèn eks-t-ek (ex)?

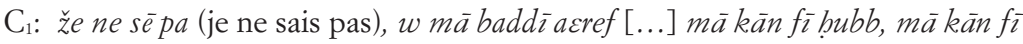
fïlin (feeling)

$\mathrm{M}_{3}$ : Where is your ex? / $\mathrm{C}_{1}$ : I don't know and I don't want to know.

\subsubsection{Insertion of phrases and interjections}

\section{Extract 5}

$\mathrm{M}_{6}$ : Ablèn, sōri aym lèit (sorry I'm late)! Kîf-kōn?

$\mathrm{M}_{4}$ : mēši-l-hāl, wēn-ak? Wì mìsd yū (we missed you)!

$\mathrm{M}_{6}: m \bar{s} d y \bar{u} t \bar{u}$ (missed you too)! 
$\mathrm{M}_{6}$ : Hi, sorry I'm late! How are you? / $\mathrm{M}_{4}$ : Fine, where were you? We missed you! / $\mathrm{M}_{6}$ : I missed you too!

Extract 6

$\mathrm{M}_{1}$ : Valentains dèy (Valentine's day)?!?! Šūfī cand-on opšons singel pīpel yacìdūn Valentains dèy (Valentine's day)? Kîf b-ta'id $\bar{u}$ ?

$\mathrm{C}_{3}$ : anā... suarè a la šondèl in front ov te miro (Soirée à la chandelle in front of the mirror)!

$\mathrm{M}_{1}$ : o no (oh no), its sō debressinn (it's so depressing)!!!

$\mathrm{M}_{2}$ : anā kamēn! Bäri bil-beyt... Ђarām, aym alō (I'm alone)!!!

$\mathrm{M}_{3}$ : lè, ai wil trìt maysēlf layk a qwin (I will treat myself as a queen), mā $\hbar a d \bar{a}$ bistabēle.

$\mathrm{M}_{1}$ : Valentine's day?!?! Do single people have options to celebrate Valentine's day? How will you celebrate it? / $\mathrm{C}_{3}$ : Me ... evening with a candle in front of the mirror! / $\mathrm{M}_{1}$ : Oh no, it's so depressing!!! / $\mathrm{M}_{2}$ : Me too, I'll stay at home, aww (also 'poor me'), I'm alone!!! / $\mathrm{M}_{3}$ : Why? I will treat myself like a queen, nobody deserves me.

\section{Extract 7}

$\mathrm{M}_{2}$ : lès tarakto? Lèt mìnōu (let me know)!

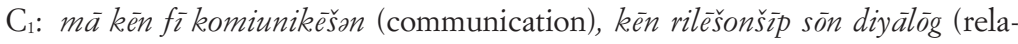
tionship sans dialogue).

$\mathrm{M}_{2}$ : Why did you leave him? Let me know! / $\mathrm{C}_{1}$ : There was no communication, it was a relationship without dialogue.

Extract 8

$\mathrm{C}_{1}$ : sè la katastrōf (c'est la catastrophe)!

$\mathrm{M}_{2}$ : lè, lēzem nkūn mudminìn $\varepsilon \bar{a}$-l-hepinès in layf (happiness in life)! Anā mudmon bass căl-positiv vaybs (positive vibes)!

$\mathrm{C}_{1}$ : It's catastrophic! / $\mathrm{M}_{2}$ : Why? We must care about happiness in life, I just care about positive vibes!

\section{RESULTS}

The samples taken from the data collected are representative of the speech habits and patterns of the two main groups studied, i.e., the Muslim and the Christian speakers. The primary interest was to confirm previous studies on the subject regarding linguistic perceptions between young people from the two communities. The samples clearly show a general tendency to recur 
to a foreign language, English or French, with a predominance of English switching for Muslim and French for Christian speakers. It is not surprising that Christians often mix with English: this is due to the strong influence of English in education.

As code-mixing and code-switching are linguistically related, their boundaries may often appear unclear. Indeed, it is not always obvious when a given element is part of code-mixing or code-switching. Moreover, the codes involved may not always be discrete items: speakers may not always be aware of which code they are using (as with the word merci or the expression $\mathrm{Hi}$ kifak ça va? 'Hallo, how are you, is it ok?') and the two languages may actually become one in their mind. What is more, as stated by Nartey (1982), the parameters for code-switching and code-mixing may not be universally applicable to all language situations. The parameters that operate in one particular environment may not operate in another, largely because cultures and communities are different, and hence behaviour is too. Speakers may employ different strategies of code-mixing and switching depending on the situation and the languages. Indeed, the Christian speakers in this study often use French among themselves, but also use Lebanese switching with English in conversations with non-Christian Lebanese, as we see in extracts 4, 6 and 7. We should also bear in mind that, as Monin (1998) observed, most television programs are in Lebanese Arabic, while 37\% are in English and only $7 \%$ in French. On the other hand, films are almost all in English: 10\% are in Lebanese or Egyptian, 6\% are in French and the remaining 84\% in English.

Insertion of individual words is also widespread in the conversations. In most cases these are not cases of code-mixing since Arabic has the equivalent terms, such as high (Ar. 'älì) or look (Ar. mą̧har), unlike words such as kamera or mübāyl (and in general all the words referring to technological devices), which, despite having equivalents in Arabic, are not common or not used, especially in Lebanon. As for the insertion of phrases, we find several cases of metaphorical code-switching, as in extract 6 , in which the insertion is used to emphasize the feeling expressed.

In conclusion, we can state that the motivations for code alternation are often interrelated; they are multidimensional and they can vary from situation to situation and from person to person. The attribution of one function rather than another to the use of a specific code may thus be relative as they are dependent on the individual situation and speaker. For this reason, it is wise to be tentative and avoid any claim of comprehensiveness in the study of these linguistic phenomena. 


\section{REFERENCES}

Atiyeh, George. 1970. "Schools of Beirut". In Beirut: Crossroads of Cultures. Ed. by Beirut College for Women, 133-66. Beirut: Librarie du Liban.

Bacha, Nahla, Rima Bahous, and Hugh Busher. 2008. "Cultures of Engagement in Challenging Circumstances: Four Lebanese Primary Schools in Urban Beirut”. School Leadership and Management 32 (1): 37-55. https://doi.org/10.1080/13632434.2011.642353.

Bacha, Nahla Nola, and Rima Bahous. 2011. "Foreign Language Education in Lebanon: A Context of Cultural and Curricular Complexities". Journal of Language Teaching and Research 2 (6): 1320-28. https://doi.org/10.4304/jltr.2.6.1320-1328.

Beer, William, and James Jacob. 1985. Language Policy and National Unity. Totowa: Rowman \& Littlefield Publishers.

Blom, Jan-Petter, and John Gumperz. 1972. "Social Meaning in Linguistic Structure: Code-Switching in Norway". In Directions in Sociolinguistics. Ed. by John Gumperz and Del Hymes, 407-34. New York: Holt, Rinehart, and Winston.

Calvet, Jean-Louis. 1987. La guerre des langues et des politiques linguistiques. Paris: Payot.

Daccache, Salim. 2013. Pluralisme, vivre-ensemble et citoyenneté au Liban: le salut vient-il de l'école? Étude comparative des finalités, des objectifs et des valeurs intracommunautaires des écoles libanaises chrétiennes, musulmanes et lä̈ques. Paris: l'Harmattan Publications.

Diab, Rula. 2009. “Lebanese University Students' Perceptions of Ethnic, National, and Linguistics Identity and Their Preferences for Foreign Language Learning in Lebanon". The Linguistics Journal 4: 101-20.

Frayha, Nemer. 1999. "The Rationale Behind Language Preference in Schools and Universities in Lebanon". Presentation at the Michigan Award Ceremony organized by the American Language Center and hosted at the Lebanese American University.

Frayha, Nemer. 2003. "Education and Social Cohesion in Lebanon". Prospects 23: 87-89.

Frayha, Nemer. 2009. “The Negative Face of the Lebanese Education System”. http://www.lebanonrenaissance.org/assets/Uploads/0-The-negative-face-ofthe-Lebanese-education-system-by-Nmer-Frayha-2009.pdf (01.10.2020).

Inati, Shams. 1999. “Transformation of Education: Will It Lead to Integration?”. Arab Studies Quarterly 21 (1): 55-68.

Joseph, John. 2004. Language and Identity: National, Ethnic, Religious. New York: Palgrave Macmillan. 
Kachru, Braj. 1978. "Code-Mixing as a Communicative Strategy in India”. In International Dimensions of Bilingual Education. Ed. by James Alatis, 107-24. Washington, DC: Georgetown University.

Monin, Pascal. 1998. "French Cultural Presence in Lebanon: What Present, What Past, What Future”. Unpublished Doctoral dissertation. Paris: Sorbonne University.

Muysken, Pieter. 2000. Bilingual Speech: A Typology of Code-Mixing. Cambridge: Cambridge University Press.

Myers Scotton, Carol, and William Ury. 1977. "Bilingual Strategies: The Social Functions of Code-Switching”. International Journal of Sociology of Language 13: 5-20. https://doi.org/10.1515/ijsl.1977.13.5.

Nartey, Jonas, 1982. "Code-Switching, Interference or Faddism? Language Use Among Educated Ghanaians”. Antbropological Linguistics 24 (2): 183-91.

(NCERD) National Center for Educational Research and Development. 2000. New Framework for Education in Lebanon. Ed. by NCERD. Beirut: NCERD.

Nydell, Margaret. 1996. Understanding Arabs: A Guide for Westerners. Yarmouth: Intercultural Press.

Shaaban, Kassim, and Ghazi Ghaith. 2002. "University Students' Perceptions of the Ethnolinguistic Vitality of Arabic, French and English in Lebanon". Journal of Sociolinguistics 6 (4): 557-74. https://doi.org/10.1111/1467-9481.00201.

Spolky, Bernard. 2004. Language Policy. Cambridge: Cambridge University Press.

Suleiman, Yasir. 1994. "Nationalism and the Arabic Language: A Historical Overview". In Arabic Sociolinguistics: Issues and Perspectives. Ed. by Yasir Suleiman, 3-24. Richmond, Surrey (UK): Curzon Press.

Suleiman, Yasir. 2004. A War of Words: Language and Conflict in the Middle East. Cambridge: Cambridge University Press.

Suleiman, Yasir, 2006. "Charting the Nation: Arabic and the Politics of Identity". Annual Review of Applied Linguistics 26: 125-48. https://doi.org/10.1017/S0267190506000079.

(UNDP) United Nations Development Program. 2009. Toward a Citizen's State. Lebanon National Human Development Report.

https://www.lb.undp.org/content/lebanon/en/home/library/democratic_ governance/the-national-human-development-report-2008-2009--toward-acitize0.html (01/10/2020). 